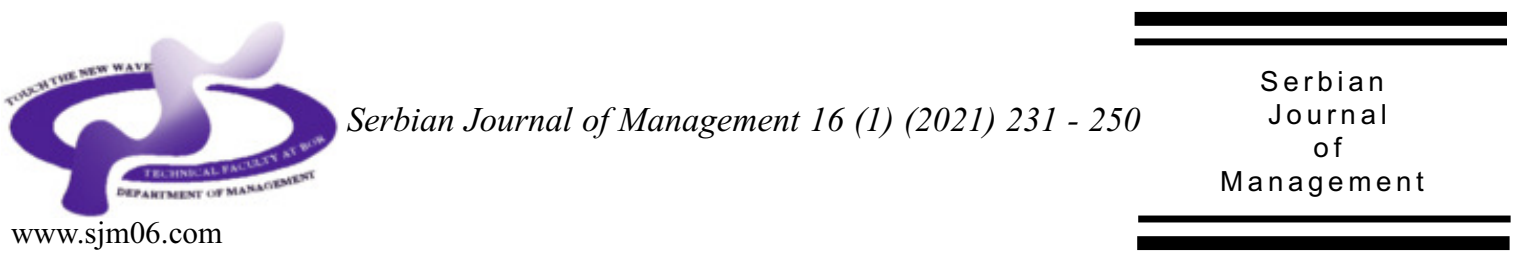

\title{
FINANCIAL SITUATION AND CHALLENGES FOR MANAGEMENT OF SME HOSPITALS: EVIDENCE FROM POLAND
}

\author{
Aleksandra Szewieczek* \\ Department of Accounting, The College of Finance, University of Economics in Katowice, \\ 40-287 Katowice, ul. 1 Maja 50, Poland
}

(Received 18 February 2020; accepted 25 February 2021)

\begin{abstract}
The hospital represents a specific organisation, operating in a turbulent environment and financed to a large extent by public funds. The health sector is exposed to constant political and social pressure. This causes significant problems with maintaining its financial stability, which particularly affects hospitals in the SME sector.

The aim of this paper is to examine the relationship between selected financial indicators and some environmental phenomena that affect the financial situation and future financial stability of a selected group of hospitals from the SME group. The results will also be compared to the situation of other SME entities. The research is based on descriptive analysis, descriptive statistics, and correlation analysis of selected data.

The results indicate that the financial situation of hospitals belonging to the SME group differs significantly from the overall SME sector, and does not bode positively for their future development. The current financial situation presents particular challenges for managers in balancing financial streams and ensuring economic sustainability. At the same time, this situation should encourage decision-makers to ensure an adequate level of revenues for these public service providers, as well as face other challenges related to operational management.
\end{abstract}

Keywords: management, hospital, health care, finance, analysis, SME

\section{INTRODUCTION}

Hospitals are distinguishable from other entities. These are comprehensive organisations, where professionals conduct specific activities. Their activity is strongly affected by political aspects, as well as their pluralistic context, organisational knowledge, legitimacy, and social capital (Pascuci et al., 2017). The healthcare system

*Corresponding author: aleksandra.szewieczek@ue.katowice.pl

DOI: 10.5937/sjm16-25276 
is focused on meeting health needs. This process includes therapeutic, preventive, promotional, rehabilitation, non-invasive treatment and other healthcare activities. The institutional dimension of performing these activities is focused on two basic forms of care - inpatient and outpatient implemented primarily by hospitals. The hospital represents one of the most important links in the healthcare system. Its activity requires a much higher level of resources than other forms of activity. The significant financial outlays, including the facilities, and resources ensuring readiness to provide services at any moment or allowing for the provision of highly specialised health services mean that the financing of their services is covered by public funds to a large extent. Hospitals may be operated as forprofit (private) or not-for-profit (also governmental) institutions, and be financed simultaneously from various public and nonpublic sources (Horwitz, 2005). The organisation and funding of healthcare varies across countries (Darvas et al., 2018; Turcotte-Tremblay et al., 2016), depending on political, economic and cultural determinants and also on the specificity, importance and costs of some health services.

The efficiency of hospitals is essential for the stability of the entire health system and its effectiveness in ensuring human health and life (Hollingsworth, 2008). Sustainable development, and the generation of financial surplus allowing for the necessary and continuous investments in modern technologies, are essential in order to ensure our citizens' health. There are many challenges faced by managers in the healthcare system. including a high level of uncertainty and the complex nature of hospitals (Pascuci et al., 2017), as well as epidemiological and demographic trends, such as an ageing population (Breyer et al., 2010), prevalence of chronic diseases, mutations of diseases and others (Rudawska, 2012). These challenges place further strain on financial resources.

However, these resources are limited while healthcare professionals report problems with balancing their financial budget, which reinforces the need for particular supervision of the effective functioning of healthcare entities. This sets out the objectives for measuring and reporting the financial results and achievements of hospitals (Pink et al. 2006; Gapenski \& Pink, 2007). The example of the last two decades in Poland shows that the financial situation experienced by healthcare entities is poor. Although it may improve periodically, this is mainly due to additional government funding (e.g. repayment of mature debt or through ownership transformation). However, this does not produce the intended effect (Babczuk \& Kachniarz, 2012). Furthermore, these funds are mainly offered to public entities whereas other healthcare institutions also experience financial problems (Bem et al., 2019; Holmes et al., 2017). The private sector does not receive additional support. As shown by international studies, additional support does not necessarily improve performance (Kaur \& Srivastava, 2017) so it is imperative to find what causes this situation. This is not, however, just a problem regarding the level of revenue, but one of seeking arguments in favour of introducing certain corrective mechanisms, including those in the area of costs, assets and liabilities. Large hospitals are usually organised under public ownership, while smaller ones are very often run privately. Such institutions have limited capacity to attract additional funding, or take 
advantage of economies of scale. On the other hand, this part of the health sector (SME) is strongly related to private investments focused on achieving financial benefits.

The aim of the research is to examine the relationship between selected financial indicators and some environmental phenomena that affect the financial situation and future financial stability of a selected group of hospitals from the SME sector in Poland. Particular attention is paid to liquidity and profitability indicators, as they are indicated as tools illustrating the stability of the company (Coyne et al., 2009). The impact of salary increase is also examined. An examination of the relationships between these quantities is particularly important while assessing the stability of operating healthcare entities and the operationalization of financial management objectives.

\section{THEORETICAL FRAMEWORK AND HYPOTHESES}

The aspects of health-care sector and macroeconomics are often presented in terms of this sector's implications for fiscal policy, including the sustainability of public debt, consequences for the labour market, human capital (Darvas et al., 2018), public health, life-expectancy, and the local economy (Doeksen et al., 1998). However, this relationship is also a two-way process. Some general macroeconomic phenomena affect the efficiency and general condition of the sector. This effect may vary, depending on the operating circumstances of individual entities. It is also stressed that the specific processes taking place in the healthcare sector are also induced by other forces, apart from common macroeconomic indicators.
Unfortunately, the lack of comparable statistical data over an extended period of time hinders effective measurement.

The source of revenue for healthcare is rather stable, while area of costs is subject to greater control. It is critical to examine cost relations and the level of average salaries, prices and other material costs, as well as income, revenue and sources of funding, as well as other financial indicators (Janati et al., 2014). Remuneration and social security costs constitute the main component of operating costs for healthcare institutions, ranging from over 50-80\% (Kazahaya, 2005). These costs are strongly dependent on the number of beds. Thanasas (2013) showed that the strongest determinant of the change in remuneration costs is the change in the number of hospital beds (approx. 74\%). Research conducted by Kalman et al. (2015) showed that the costs of (indirect) remuneration strongly influence the increase of overhead costs. The subject of the survey concerning the financial results in various enterprises concerns both internal relations (Mohanty \& Mehrotra, 2018) and the impact of environmental and macro-economic variables (Schumann, 2008). At the same time, until the mid-1990s, in the United States one can observe that the growth rate of remuneration costs in health care was higher compared to the economy as a whole. But in the following years this situation reversed. Simultaneously, the growing demand for health care, resulting in an increase in the demand for human resources, leads to the conclusion that hospital wages will increase faster than in other industries (GlobalInsight, 2002). Similar conclusions apply to Canada, where the earnings of health professionals have increased at a higher rate than in the general economy, which poses a challenge for the government (Canadian, 2011). The 
above leads to the formulation of the first hypothesis:

H1. There is a strong pressure on remuneration increase in the healthcare sector, resulting in a much higher growth rate than in other sectors of the economy

Meyer et al. (2014) stressed that the hybrid nature of non-profit hospitals sets additional challenges for managers who need to combine economic and financial sustainability with inherent social dimensions. Particular challenges for this group of hospitals have been also highlighted by other researchers (Etizoni, 1964; Horwitz, 2005; Locke \& Spender, 2011). Studies have also been conducted taking into account the size of hospitals (Augurzky \& Schmitz, 2010; Younis, 2012). Smaller hospital are often thought to generate higher costs than bigger hospitals, mainly because of the economy of scale (Street et al., 2010). From this perspective, entities classified as SMEs, so important for the proper functioning of the economy, may also be examined (Mohanty $\&$ Mehtrora, 2018). This group may be compared with other sectors or even the general economy (Young \& Ballarin, 2006). This marks another area of particularly important social and economic research on financial management in hospitals from the SME sector. Such research may help the healthcare sector function more effectively.

In order to improve financial stability and achieve cost reduction companies may implement various cost reduction strategies, e.g. continuous improvement (Koval et al., 2019). This requires an analysis of whether the health care sector is affected by phenomena other than those typical of the economy as a whole. The research conducted in this area concerns the relationship between the finances of healthcare systems and the economic situation (Ryć \& Skrzypczak, 2012). The research may also investigate selected areas of hospitals' internal financial status. As indicated by Zeller, Stanko and Cleverey (1996), 6 areas may be analysed in this respect: profitability, fixed-assets efficiency, capital structure, fixed-asset age, working capital efficiency, and liquidity. The objective of the research is also to find connections between liquidity and profitability (Mohanty \& Mehrotra, 2018). Variables such as net profit margin, short-term solvency, debt, business size, legal form, GDP, and others are analysed in terms of the profitability of hospital companies (Creixans-Tenas, ArimanySerrat, 2018). Many researchers also highlight that in many southern and eastern EU countries, some difficult economic circumstances have stifling effects on SME development (www1, 2018; Horgan et al., 2018). SME entities have to face higher fixed costs arising from overregulation and a bureaucratised administrative system (Horgan et al., 2018). Smaller firms are often more dynamic and innovative than larger ones but are simultaneously more unstable. Nearly half of all start-ups are expected to fail within 5 years, and only a few will grow to become large firms (Report on Support to SMEs, 2011).

Bearing in mind the strong pressure on remuneration increase in the healthcare sector, as well as the other phenomena previously, it is possible to induce that the financial position of SME hospitals will be weaker compared to the economy as a whole. Complementing the lack of research in relation to the overall SME sector, we formulate the second hypothesis:

H2. Observation of trends regarding fluctuating financial flows in SME hospitals 
compared to the overall SME sector reveals that their financial position will deteriorate in the near future.

To face the challenges of a changing and demanding environment, it is necessary to integrate areas of operational and strategic management of healthcare units with phenomena occurring in the general economy and to assess the impact of these phenomena. At the same time, SME companies face developmental issues, e.g. product registration, reimbursement, procurement, distribution channels, health technology assessment and access to R\&D incentives (Final report, 2018). This is strongly connected with their inability to make use of local funding sources, as well as a strong dependence on banking and similar sources of finance (www2, 2018). As indicated by other studies, access to financial sources is more difficult for SMEs than large entities (Kirshbaum et al., 2017). Moreover, SMEs in developing countries face significant barriers to finance. The major weakness of SMEs is a lack of capital, which then constrains development and even dayto-day operational management (Milosevic et al., 2019). The World Bank Enterprise Survey showed that in low-income countries, approximately $40 \%$ of SME entities (20-99 employees) claim that access and cost of finance imposes a major limitation on ongoing operations (Report on Support to SMEs, 2011). On the other hand, SMEs tend to prefer internal financing over external debt, also because of the cost of borrowing money. Firstly, SMEs rely on retained earnings, and only if there is a lack of such resources will they seek external financing (Odit, Gobardhun, 2011), which obviously has a major impact on their leverage. High administrative costs, high collateral requirements and lack of experience with financial intermediaries are also relevant (Report on Support to SMEs, 2011). Firms focused on short-term return on investment and financial performance are unlikely to be competitive in the long term (Mills et al., 1998; Ates \& Bitici, 2009).

Hospitals, sensing the turbulence described above, implement various strategies for shaping financial streams and indicators, which do not always turn out to be effective. Furthermore, hospitals tend to operate on small margins (which is visible from the example of the net profit margin indicator), which represents a challenge for managers to implement strategies that provide sustainable financial surpluses for the maintenance and development of these organisations (Collum, 2013). This extends the research scope to include the determinants of a hospital's financial liquidity (Bem et al., 2014). Their results are critical to assess the condition of an enterprise and its likelihood of staying in business. It is also proven that the financial condition of a hospital affects the quality of patient care (Bazzoli et al., 2008). In this area, various evaluation tools are used, such as the evaluation of an activity's effectiveness, financial ratios, return on assets (ROA), return on equity (ROE), return on capital employed (ROCE) etc. It is worth referencing these methods of evaluation to the sector as they are governed by different principles and are more or less susceptible to specific phenomena occurring in the environment. It is therefore possible not only to study internal relations, but also the impacts of external phenomena of a macroeconomic nature. Hospital financial performance is also examined in terms of links with the development of quality management strategies (Smythe et al., 2009; Velez-Gonzales et al., 2011) and the impact 
of a hospital's profitability on the structure of its liabilities (Bem et al., 2015) and other explanatory factors (Creixans-Tenas, Arimany-Serrat, 2018).

SME managers use limited application of strategy management tools and techniques, so the SME strategy process tends to involve a market based view (Ates \& Bitici, 2009). Therefore, the problem for SMEs is the lack of sufficient knowledge about financial management, which may negatively affect profitability (Muneer et al., 2017). If we compare the above phenomenon with the fact that financial health of the SMEs is in bad shape, as is visible from their low profitability indices (Nyabwanga et al., 2013), we can state the third hypothesis:

H3. A survey of selected financial indicators found that hospitals in the SME sector are characterized by a prudential operational management strategy.

The research is based on a meta-analysis of the literature, analysis of financial data of hospitals belonging to the SME sector in Poland, and statistical data collected in the system of Statistics Poland (GUS). The research results and final conclusions were developed using the descriptive statistical method, the Spearman correlation analysis, and inductive reasoning.

This paper contributes to bridging the gap in the literature on the micro strategies recommended by Pascuci et al. (2017), indicating the financial aspects of internal and external relations that are relevant to the operational management of SME hospitals. This study provides evidence that the financial situation of hospitals in the SME sector is unsatisfactory, which hinders the necessary development of these facilities. This situation makes it difficult to improve access to healthcare services. The healthcare sector is characterised by the influence of specific factors, strong pressure on salary increase, stable (rigid) levels of income and maladjustment to cost levels. As a result, managers of healthcare entities apply a strategy of prudential operational management.

This study also aims to broaden research on the financial position of SME health care entities and, as a result, contribute to research concerned on internal financial aspects of the SME sector.

\section{RESEARCH BACKGROUND - A POLISH PERSPECTIVE}

There are currently more than 1,000 hospitals in Poland. It is impossible to evaluate their exact number due to the lack of a uniform methodology for their qualification and data source. It is worth noting that this group includes all entities, even if they have only a few hospital beds.

In Poland, there is a universal system of funding healthcare services, based on the national insurance model. The public funds are collected from national insurance contributions, which are universal and obligatory. Healthcare is also financed from private funds, although this is mainly used for ambulatory care and pharmaceuticals. Consequently, there is limited access to healthcare services, additionally strengthened by limited availability of other resources (Szewieczek, 2018; Darvas et al., 2018). There is also a genuine deficit in hospitals' budgets. The low level of expenditure on healthcare should be indicated as the primary cause of financial problems in the healthcare sector, which also induces other negative impacts, such as departure from the profession, and the 
migration of health professionals. This is particularly evident in Poland when compared to the spending levels in other OECD countries (table 1).

The level of health expenditure in Poland is rising, but its growth rate is still lower than in most OECD countries. Public expenditure is dominated by just one source - the National Health Fund, at a level of $85 \%$ and supported by the state budget (11\%) and local government budgets (4\%) (Health and health care in 2017, 2019). The trend towards higher health spending is both: visible and inevitable, and it is linked to the effect of many factors, including an ageing population and technological progress (The 2018 Ageing Report, 2018; Breyer et al., 2010).

\section{METHODOLOGY}

The research is concerned with fluctuations in sales revenues, costs and net results in selected SME hospitals (assets, net income, net revenue and total debt), as well as cost of wages and remuneration trends against the background of analyses of selected financial data for the period 20142017 in SME hospitals). To analyse the relation of selected financial flows, the capacity to develop hospital activities and introduce different strategies, our investigation moves on to probe the correlation between selected variables of
SME hospitals in Poland.

The research sample consist of 53 small and medium-sized non-profit hospitals. The prior sample of 474 entities was limited only to those entities which operate according to the Polish classification of hospital activity. Financial data were collected from financial statements accessible for the period 20142017. As a result, the final financial data collected from hospitals used for statistical analysis consist of max. 212 observations. The financial data used for the research were obtained from the EMIS Intelligence base. Detailed information about the sample is presented in Table 2. All presented financial data is expressed in thousands of Polish zlotys (thousand PLN).

To accomplish the research aims and test the hypotheses, the empirical part of the study is organised in two parts. Initially, we visualise and analyse the trends in selected financial streams of the surveyed healthcare units, including making comparison with the entire SME sector. The second part of the research includes descriptive statistics and correlation analysis between selected variables. The correlations between the presented variables were calculated using Spearman's correlation analysis due to the fact that the observations lack focus. The level of significance is 0.05 and critical value for T-student test is: $<\infty ;-1,97132>$ or $<1,99132 ; \infty>$.

Our research in this area is partially based on previous studies conducted in the SME

Table 1. Health care expenditures in Poland in \% of GDP

\begin{tabular}{lcccc}
\hline Expenditures & $\mathbf{2 0 1 3}$ & $\mathbf{2 0 1 4}$ & $\mathbf{2 0 1 5}$ & $\mathbf{2 0 1 6}$ \\
\hline Current expenditure in \% GDP & $6.38 \%$ & $6.25 \%$ & $6.34 \%$ & $6.52 \%$ \\
- incl. public expenditure & $4.51 \%$ & $4.42 \%$ & $4.44 \%$ & $4.55 \%$ \\
- incl. private expenditure & $1.87 \%$ & $1.83 \%$ & $1.90 \%$ & $1.96 \%$ \\
Current expenditure in \% of GDP - average for OECD countries & $8.9 \%$ & $9 \%$ & $9 \%$ & $9 \%$ \\
\hline
\end{tabular}

Source: based on (Health and health care, 2017, 2019; Health at ..., 2015; Health at ...., 2017) 
Table 2 Sample characteristics

\begin{tabular}{|c|c|}
\hline Hospital characteristics & Additional information \\
\hline Sample size: 53 & \multirow{3}{*}{$\begin{array}{l}\text { Due to the base limitations it was not possible to collect data } \\
\text { before the year } 2014\end{array}$} \\
\hline Prior sample size: 474 & \\
\hline Status of the firm: Active & \\
\hline Number of employees $<250$ & \multirow{3}{*}{$\begin{array}{l}\text { The group is presented by non-public hospitals; that is due to the } \\
\text { fact that public hospitals dominate in larger sizes of activity }\end{array}$} \\
\hline Sum of assets $<43$ million euro & \\
\hline Net turnover $<50$ milion euro & \\
\hline $\begin{array}{l}\text { Data accessible for the year } \\
\text { 2014-2017 }\end{array}$ & $\begin{array}{l}\text { The sample consists of hospitals that presented important } \\
\text { financial data for the entire period (2014-2017) }\end{array}$ \\
\hline Sector NAICS Hospitals: 622 & \multirow{3}{*}{$\begin{array}{c}\text { In first step NAICS classification was used (474 entities), second } \\
\text { step was connected with exclusion of medical practices and } \\
\text { similar activities (53 entities) }\end{array}$} \\
\hline $\begin{array}{c}\text { Sector PKD } 2007 \text { (Polish Classification } \\
\text { of Activities) }\end{array}$ & \\
\hline Hospital activity $(86.10 . \mathrm{Z})$ & \\
\hline
\end{tabular}

sector by Mohanty and Mehrotra (2018). The results of the research are compared to the results obtained from the baseline model in order to present the situation of hospitals against the selected background. While reducing variables to a certain degree, resulting from the specific nature of the healthcare activity, we identified the following groups of variables:

- Dependent variables: Net profit margin (NPM), return on assets (ROA), return on capital employed (ROCE), which represent profitability of the examined hospitals. The presented outcomes are used as representatives of the studied SME sector performance and profitability.

- Explanatory (independent) variables: current ratio (CR), quick ratio (QR), which represents the liquidity of the studied hospitals. These variables are used to predict the values of the dependent variables. Ratio indicators are strongly associated with cash flows that significantly shape the financial condition of health care entities.

- Control variables sales growth rate (SGR), financial debt ratio (FDR), as these variables may directly affect cash flows and profitability ratios in studied companies, but they are not the main focus of the research. The presented variables may have an effect on the results.

All variables were calculated based on the surveyed financial statements:

NPM net profitability margin $=$ net profit/sales

ROA return on assets $=$ net income/total assets

ROCE return on capital employed $=$ operating income/total capital employed

CR current ratio $=$ current assets/current liabilities

$\mathrm{QR}$ quick ratio $=$ (current assetsinventory)/current liabilities

SGR sales growth rate = (curren sales-last year sales)/last year sales

FDR financial debt ratio = total debt/total assets

\section{RESULTS}

The study analysed the fluctuations of sales revenues, costs and net result (figure 1) and the concentration of sales revenues relative to the results of operating activities in 2014-2017.

In the period studied (2014-2017), an increase in sales revenues, costs and operating results can be observed. The location of revenues exceeding the median is 


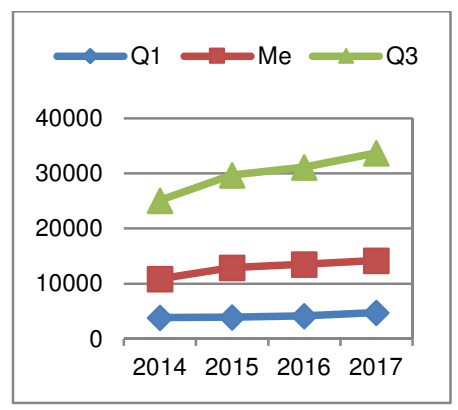

REVENUES

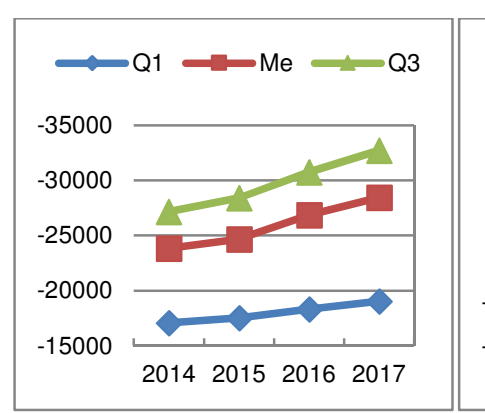

COSTS

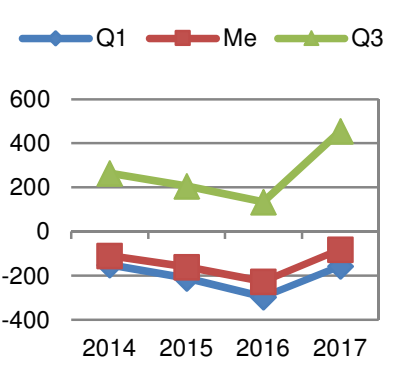

NET INCOME

Figure 1. Financial results in SME hospitals for the period 2014-2017 (in thousands PLN)

more distant than the analogous situation in terms of operating costs. However, in terms of net results, the median results are similar to the first quartile (Q1). It is worrying that both the median and the first quartile of operating results in hospitals are in the red. This means that a significant number of the studied hospital generate negative operating results. What is also worrying is that during the first three years, these results deteriorated. In the same period almost half of the studied hospitals achieved a rather stable level of income. One can only notice a visible increase in income level in hospitals in the third quartile. The evaluated trend lines clearly show a higher cost line rising over revenue in all ranges. However, the reduction in the difference in trends in the last analysed period may be reflected as positive, and may indicate a reversal of negative relations.

Extending the results presented in the previous figure, it can be seen that in the examined hospitals, there is a concentration of revenues (horizontal axis) and results (vertical axis) within the range of low level results and revenues. There are a few cases that vary from this rule, which show mainly positive financial result (figure 2).

The results in individual years and the trend lines reveal slow increases, though diverse in subsequent years. The year 2014 turns out to be similar to 2017, while the highest growth line was determined in 2015 . One can also observe that the presented results are strongly concentrated around the volume of low financial results. However, it is also clear that the more revenue a hospital receives, the higher the operating results that are generated.

It is possible to compare the measure of variability of the net financial results of hospitals in the SME group with the overall results of SME companies (figure 3) published by Statistics Poland (www3).

The results determined for the examined set indicate that the results of the hospital sector (total of net results in the group) are much lower than the total of results for the whole group of the SME sector. It is also worrying that after 2016, the trend lines of these groups slightly deviate from each other, with values slightly falling for the hospitals while the whole sector is growing significantly. When we compare it with the results presented in previous figures (figure $1,2)$ we can conclude that the positive growth in the trend line of hospitals' operating results is worth nothing when compared with the entire SME sector. This 
situation strongly affected the capacity for development, strategic management and the position of the health sector in the general economy. There could be many reasons for such disparities. While looking for the causes of these tendencies, it should be taken into account that the basic cost in the operation of hospitals is human labour. The following figure (figure 4) shows basic information in this respect.

Due to the limited access to data, it was impossible to determine the trend in the institutions surveyed over a longer period of time. Furthermore, it can be noticed that the growth rate for remuneration costs (all the costs connected with the employees) in the entities surveyed is significantly higher than the general trend in the economy. It is also worrying that the sector is also largely diverging (upwards) from pay increase in the corporate sector. The Pearson's correlation coefficient for the trend regarding pay increase in the healthcare sector and the economy as a whole was 0.82 , but in statistical terms, this result is negligible $(p=0.63)$, which may be connected with the small sample size and short research period. Nevertheless, the predominance of average renumeration increase in health care is worrying especially when combined with the presented financial results. Of course it is possible that other phenomena affect renumeration costs in hospitals, although we can not demonstrate this within the audited period.

The variability of financial results in the period studied was significant, and the value of assets and revenues, as well as employee cost and debt, fluctuated significantly (table 3). Coefficient variation was significantly

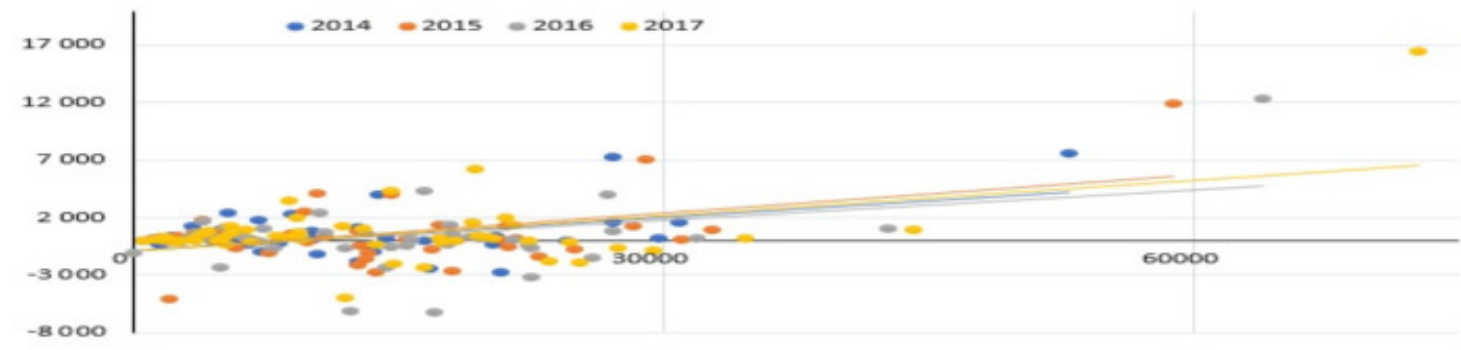

Figure 2. Dispersion of revenues and operating results in SME hospitals in the period 2014-2017 (in thousands PLN)

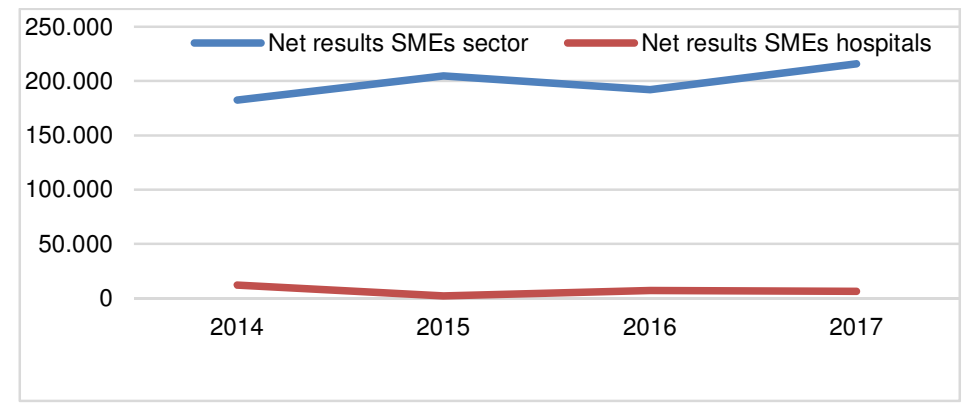

Source: own study (based on: Statistical Yearbook..., 2018; www3)

Figure 3. Sum of financial results of SME hospitals against all SME sector (in thousands PLN) 


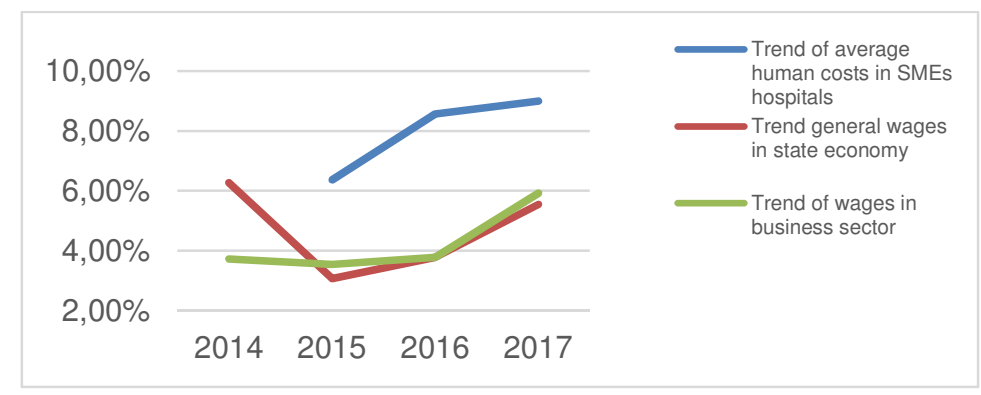

Source: own study (based on: Statistical Yearbook..., 2018; www3).

Figure 4. Cost of wages and their trends

high. The unstable financial situation of the relationships and the level of their institutions was reflected, among others, in a significance (table 4).

very high variation $(\mathrm{CV})$ of net income. Against this background, the source of revenue (results) turns out to be the most stable. The high maximum value of debt is also noteworthy, which, in relation to the analogous measure of revenue, accounts for over $50 \%$ of its value.

Descriptive statistics for the independent variables, control variables and dependent variables were analysed to determine the variability of each, to test their mutual

The mean values of CR $(2.49 ; 1.25)$ and QR $(2.25$; 1.12) indices are at the correct level. Even hospitals in the first quartile show relatively good results. Medical entities tend to limit their inventories, which means small differences between CR an QR ratios. On the other hand, the sales growth rate (SGR) is extremely dispersed (min: 47.88; max: 673.17; CV: 4.39), which indicates that the data in the surveyed units are significantly diversified. The average

Table 3. Descriptive statistics of selected financial data for the period 2014-2017 of SME hospitals

\begin{tabular}{cccccccc}
\hline Variables & CR & QR & SGR $(\%)$ & FDR $(\%)$ & ROA $(\%)$ & ROCE $(\%)$ & NPM(\%) \\
\hline Arith. Mean & 2.49 & 2.25 & 14.24 & 61.59 & 5.78 & 12.83 & -0.81 \\
Me & 1.25 & 1.12 & 5.08 & 49.63 & 1.86 & 5.82 & 1.30 \\
Q1 & 0.76 & 0.69 & 0.85 & 24.90 & -3.86 & -2.65 & -2.39 \\
Q3 & 2.41 & 2.24 & 12.64 & 75.73 & 11.83 & 19.36 & 6.77 \\
Min & 0.05 & 0.01 & -47.88 & 3.82 & -141.16 & -770.87 & -353.00 \\
Max & 21.09 & 19.71 & 673.17 & 840.13 & 216.39 & 1257.03 & 37.13 \\
Std. Dev. & 3.58 & 3.24 & 62.49 & 84.01 & 31.92 & 121.25 & 33.03 \\
CV & 1.44 & 1.44 & 4.39 & 136.40 & 552.70 & 09.45 & -4069.03 \\
\hline
\end{tabular}

Table 4. Descriptive statistics of variables used

\begin{tabular}{cccccc}
\hline Variables & Assets (total) & Net income & Net revenues & Employee cost & Total debt \\
\hline Arith. Mean & 12,575 & 128 & 12,258 & 4,790 & 6,656 \\
Min & 43 & $-13,601$ & 484 & 40 & 39 \\
Max & 98,202 & 12,852 & 72,620 & 23,081 & 39,275 \\
Std.Dev. & 15,573 & 2,264 & 11,389 & 5,102 & 8,614 \\
CV & 1.24 & 17.67 & 0.93 & 1.07 & 1.29 \\
\hline
\end{tabular}


negative profit margin $(-0.81)$ and the median of this margin $(1.30 \%)$ only just in the black indicate the low profitability of this type of activity and difficulties in generating surpluses that might enable further development. A huge disparity in the margin level is noticeable in the $\mathrm{CV}$ indicator. The position of the financial debt ratio (FDR) between the median (49.63) and Q1 and Q3 (24.90 and 75.73 respectively) would tend to indicate a model pattern in the group studied. At the same time, the debt strategy is implemented in a prudent manner, as it is placed on average within approx. $60 \%$ of assets. It is possible, however, that this level is higher but an in-depth analysis of the level of the financial result is needed. The high level of standard deviation (84.01) and coefficient of variation (136.04) for SGR is also worrying, as it also shows that the financial situation of the entities studied is extremely heterogeneous.

A correlation of indicators in the units surveyed is presented in table 5 .

Due to the rather large sample size, almost all the results are statistically significant. Only SGR and FDR relations, as well as SGR and NPM, do not share this feature. The analysis of correlations revealed that there was a very strong relationship between CR (current ratio) and QR (quick ratio), confirmed as statistically significant. Such results in the healthcare sector are not surprising since inventory levels are low.

Examining dependent variables should be indicated that there is very strong relationship (0.9403) between ROA (return on assets) and NPM (net profit margin), while such a relationship is quite strong (0.8279) between ROCE and NPM. ROA also shows a positive moderate correlation with CR (0.4873) and slightly weaker (although still moderate) with QR (0.4734). The results indicate the weak susceptibility of the ROCE indicator to the indicated variables ( 0.3450 with $C R ; 0.3573$ with $Q R)$ and virtually no dependence (very weak) with other financial indicators (SGR and FDR). Furthermore, the relationship between ROA and FDR (financial debt ratio) is weak and negative. Research results indicate no statistically significant relationship between SGR (sales growth rate) and NPM, or between SGR and FDR, as well as a lack of significant influences from SGR and any of the variables surveyed.

There is also a negative but moderate correlation of CR (-0.6041) and QR (0.5722 ) with FDR (statistically significant), which confirms the idea that as liquidity increases, the level of debt in these units decreases and vice versa. A similar, albeit weak (0.3847), relationship occurs between FDR and ROA. Consequently, one can

Table 5. Spearman correlation matrix between selected variables of SME hospitals in Poland

\begin{tabular}{crrrrrrr}
\hline & \multicolumn{1}{c}{ CR } & QR & SGR & FDR & NPM & ROA & ROCE \\
\hline CR & 1 & & & & & & \\
QR & 0.9947 & 1 & & & & & \\
SGR & -0.1715 & -0.2107 & 1 & & & & \\
FDR & -0.6041 & -0.5722 & 0.2619 & 1 & & & \\
NPM & 0.4103 & 0.4049 & 0.1311 & -0.3083 & 1 & & \\
ROA & 0.4873 & 0.4734 & 0.2080 & -0.3847 & 0.9403 & 1 & \\
ROCE & 0.3450 & 0.3573 & 0.1536 & -0.2256 & 0.8279 & 0.8798 & 1 \\
\hline
\end{tabular}

Note: The level of significance is 0.05 (results are statistically significant) 
observe that liquidity moderately affects solvency and return on assets, which means that there are also other phenomena that affect these areas.

In summary, the correlation indicates a very strong relationship between ROA and NPM only, as well as CR and QR (which may seem obvious), a strong relationship between ROCE and NPM, as well as ROCE and ROA. The results clearly indicate that moderate correlations are dominant (CRFDR; CR-NPM; CR-ROA; QR-FDR; QRNPM; QR-ROA). The impact of such variables as sales growth ratio (SGR) and financial debt ratio on dependent variables (FDR) is weak.

\section{DISCUSSION}

Our research on the pattern of financial streams of revenues, costs and financial results in the entities surveyed leads to the conclusion that there are significant differences in this respect. The visualisation of revenues shows a significant deviation of the value of the third quartile (Q3) from the median compared to the distribution of the first quartile (Q1). The opposite is true for costs. Furthermore, a much higher rate of increase in the level of costs in the analysed years compared to the increase in revenues can be observed. With the average level of profit in the entities being low and fluctuating significantly in the periods surveyed (236 thous. PLN in 2017, 12 in 2016, 137 in 2015 and 113 in 2014), this situation does not encourage optimism. Another worrying fact is the quantity hospitals studied with low sales revenues and operating results, or even a negative balance (figure 2). Such instability experienced by smaller entities is consistent with the results presented in the report (Report on Support to SMEs, 2011).

Interpretation of these values along with trends in the financial results of the hospitals in the SME sector compared with the results of all entities in the SME sector in Poland in 2014-2017 leads to the conclusion that the situation facing hospitals is not only much worse but is also heading in the wrong direction. The results achieved by hospitals continue to be poor (and even slightly worse), whereas the SME sector as a whole not only fares significantly better, but also substantially improves. Extending the research to analyse the basic cost element in healthcare, i.e. remuneration, points to much worse implications. Despite the limited data set, the analysis of statistical dependencies does not provide meaningful guidance in this respect. However, it is possible to indicate a much higher rate of increase in salary costs than in the sector in general, even when compared to the business sector. This allows us to prove the first hypothesis, that there is a strong pressure on salary increase in the healthcare sector, resulting in a much higher growth rate than in other sectors of the economy. We can also prove the second hypothesis in as much as observation of financial flow trends in SME hospitals compared to the overall SME sector reveals that their financial position will deteriorate in the nearest future. However, we should also notice that weak financial health is emphasised across the entire SME sector (Nyabwanga et al., 2011). These results can be partially compared with those presented by Augurzky and Schmitz (2010) and Younis (2012), which revealed that small hospitals generally face more financial difficulties than large ones. Admittedly, these studies only involved the medical sector, but in our opinion, they may be relevant nonetheless. 
We may also conclude that if this trend is not followed by an increase in revenue, the situation of these institutions will deteriorate significantly. Furthermore, it is possible to indicate that the situation of the entities surveyed is also unstable. The coefficients of variation for basic financial data vary significantly. The most stable results only concern stable revenue resulting from the relative rigidity in financing health services by the payer. This also suggests that the revenue streams are not adjusted to the increasing salary expectations and other cost-generating phenomena in the healthcare sector.

With respect to the above mentioned instability of the functioning of the entities surveyed, this is confirmed by a significant variation in terms of descriptive statistics regarding the selected variables in the group of hospitals surveyed (table 4). With the size of the group studied and its association with the SME sector, these fluctuations may significantly diversify the results of operations and have a strong effect on the development of these entities. Such instability undoubtedly imposes a limitation on prudential strategy. The results of the research indicate low profitability, which significantly limits investment strategies, and therefore determines the weakening of the market position at the same time.

This may translate into a prudential debt shaping strategy used by the entities surveyed, not exceeding $60 \%$ of assets. At the same time, ROA reached an average level of $5.78 \%$, which is much better in hospitals than in a study by Bem et al. (2018), who found this value to be negative (-0.03). Furthermore, in this study, entities with a low possibility of financial distress showed positive values of ROA (0.02), which allows for optimistic conclusions concerning the hospitals studied, in terms of the values currently examined. This is also confirmed by the correct liquidity ratios (especially QR Me 1.12, average 2.25; while CR Me 2.49, Me 1.25). This may also indicate a prudential strategy undertaken by management and some accumulation of funds, as confirmed by the results found by Collum (2013), who demonstrated that managers, in order to ensure financial stability, should choose strategies that are more susceptible to their control. These results are partially inconsistent with the results presented by Nyabwanga et al. (2011), studied for a different SME company, whose liquidity position was well below the acceptable norm (2 for $\mathrm{CR}$ and 1 for $\mathrm{QR}$ ). The presented results are partially consistent with those presented by Odit and Gobardhun (2011) that SME profitability is negatively related to long term debt, although we did test the relationship between FDR and NPM and proved that this correlation is rather weak (0.3083).

The analysis we performed revealed the presence of a moderate, negative correlation between liquidity ratio (CR and $\mathrm{QR}$ ) and debt ratio (FDR). The results presented are different from the results in the entire SME sector, presented by Mohanty and Mehtrora (2018). However, these results are partly consistent with a previous study conducted among a group of 67 hospitals in Poland by Bem et al. (2014), who found a significant negative correlation between debt ratio and liquidity. This means that they may be regarded as significant in the assessment of hospital activity.

We did not confirm any significant correlation between ROA and FDR. This relationship is weak, as is the one between ROCA and FDR. In light of the results, an increase in ROA shapes FDR to a very 
limited extent. Furthermore, such indications have not been confirmed in general studies looking at the entire sector (Mohanty and Mehtrora, 2018). If such a relationship did exist, the level of debt would decrease, which may result from either an increase in assets (i.e. the first case) to a greater extent than the increase in debt or an increase in debt with less changes in assets.

By comparing this relationship to the results obtained by the entities surveyed, it can be concluded that an increase in the debt associated with the worsening of the financial situation of hospitals is probable. Another (positive) cause may be developmental activities. These results encourage further research, also compared to the findings of Bem et al. (2015a), who demonstrated that hospitals with a high return on assets (ROA) were characterised by a high level of debt. Our research also confirms this partially, as we can observe that the median of ROA for the hospitals included in the study is $1.86 \%$,with FDR of $5.08 \%$, while hospitals in the third quartile show $11.83 \%$ and $75.73 \%$ respectively. Furthermore, prudential strategy indicates that hospitals with low profitability use debt on a smaller scale then the most profitable hospitals, which had higher debt ratio then the less profitable hospitals. A very strong and positive correlation was also confirmed between ROA and NPM (0.9403). This shows that as the net margin increases, the ROA indicator also rises, which is the effect of either stabilisation in the level of assets in relation to the growth of income or, at most, their slower growth rate in relation to the growth of income. A similar situation occurs in the relationship between net profit margin and ROCE, but this impact is little lower (0.8279). The results of the study did not confirm the relationship between net profit margin and financial debt ratio (a weak relationship of -0.3083).

Bearing in mind the above - and the categorisation of variables into dependent, independent and control - we can conclude that there is only a moderate relationship between return on assets and liquidity ratios, which is not affected by changing revenues. Simultaneously, this relationship may be partially impaired by the level of debt, as financial debt ratio has a statistically important negative impact on return on assets $(-0.3847)$.

\section{CONCLUSIONS}

This study focuses on the financial situation of SME hospitals and their strength to develop. This situation has been analysed not only from the perspective of the organisations studied, but against the background of relevant, general economic phenomena. The financial situation of SME hospitals is described in comparison with the whole SME sector in Poland, which yields additional conclusions regarding the organisation of this sector.

The presented research confirmed that the hospitals studied tend to use prudential strategies for shaping selected financial components, along with assets and liabilities. The first part of the survey indicated that in the context of the instability and poor financial position of the entities surveyed, such an approach does not raise doubts. However, it represents an important guide for policy-makers in shaping the organisational and legal conditions for institutions from this sector. Consideration should be given to actions that might be undertaken to develop these units and make the necessary investments. Healthcare is a 
sector that requires continuous development in order to meet growing social needs and new disease risks.

In conclusion, it should be stated that the financial management of healthcare entities is much more demanding than in other sectors of the economy, whereas their profitability and financial stability is incomparably worse than in other entities of the SME sector. The studied sector is also characterised by partial dissimilarity of the relations between the variables studied. Consequently, this sector is not attractive for private investors. The state should therefore not only support the public sector, but also encourage private investors to increase their investments. Of further concern is the fact that in Poland the level of health expenditure is rising, but its growth rate is still lower than in most OECD countries. This is another factor limiting investors' interest in this sector, but also has a significant impact on the quality and accessibility of health services

The presented research results have limitations that mainly concern the period within which the research was conducted. Unfortunately, due to the limited database accessibility it was not possible to obtain data for a period longer than 4 years (20142017). This significantly limited the possibility to evaluate the trends in the relationships between the financial data in the healthcare sector. Another limitation, also connected with the studied period, is the rather small sample size, limited due to database restrictions. The restricted sample size poses a limitation in terms of the results presented, which have to be generalised. Another limitation is also incomplete delivery of data by the statistics system, as a result of the adopted assumptions as well as organisational and formal constraints. The limitations also include a significant variation in financial values in the sample of entities studied. At the same time, this proves how diverse the circumstances of the institutions in this sector are.

Despite the several limitations mentioned, this research constitutes a contribution to the field of operational management of healthcare entities and in the process of identification and communication of the specificity of how healthcare institutions operate. It also provides guidance for the implementation of management strategies in these entities. The presented study contributes to literature by bringing new research results based on empirical data and facilitating comparison with previous research. Most importantly, the presented results fill a gap in research on the SME sector.

This research would also appear to be a very important tool for the assessment of an institution's financial situation, e.g. in the area of investment. It can be explored by health care managers, to develop their knowledge of the interaction between the financial aspects of health care activities as well as selected influence of the external environment. Furthermore, these findings should be used by policy makers as they indicate a clear financial weakness manifested by SME hospitals. This should be the starting point for taking fundamental action to improve the financial situation in health care.

Furthermore, the study represents an initial stage, which in the following years will be continued within an extended time horizon. The study we will also be continued with an extended study sample, which will allow for more detailed financial analyses involving not only SMEs. 


\section{ФИНАНСИЈСКА СИТУАЦИЈА И ИЗАЗОВИ ЗА УПРАВЉАЊЕ} МСП БОЛНИЦАМА: ДОКАЗИ ИЗ ПОЉСКЕ

\section{Aleksandra Szewieczek}

\section{Извод}

Болница представља специфичну организацију која делује у турбулентном окружењу и у великој мери се финансира из јавних средстава. Здравствени сектор је изложен сталном политичком и социјалном притиску. То узрокује значајне проблеме са одржавањем његове финансијске стабилности, што посебно погађа болнице у сектору МСП.

Циљ овог рада је да испита однос између изабраних финансијских показатеља и неких феномена окружења који утичу на финансијску ситуацију и будућу финансијску стабилност одабране групе болница из групе МСП. Резултати ће се такође упоређивати са ситуацијом у другим субјектима МСП-а. Истраживање се заснива на дескриптивној анализи, дескриптивној статистици и корелационој анализи одабраних података.

Резултати указују да се финансијска ситуација болница, које припадају групи МСП, значајно разликује од укупног сектора МСП и не утиче позитивно за њихов будући развој. Тренутна финансијска ситуација представља посебне изазове за менаџере у балансирању финансијских токова и осигурању економске одрживости. Истовремено, ова ситуација треба да подстакне доносиоце одлука да осигурају адекватан ниво прихода за ове пружаоце јавних услуга, као и да се суоче са другим изазовима у вези са оперативним управљањем.

Кључне речи: менаџмент, болница, здравствена заштита, финансије, анализа, МСП

\section{References}

Ates, A., \& Bitici, U. (2009). Strategy Management in Small to Medium-Sized enterprises: Evidence from UK manufacturing SMEs. Proceedings of the 16th annual EUROMA Conference, Göteborg, Sweden, June 14-17.

Augurzky, B., \& Schmitz, H., (2010). Is There a Future for Small Hospitals in Germany? Ruhr Economic Paper, 198, 1-17.

Babczuk, A., \& Kachniarz M. (2012). Sources of Soft Budget Constraints in the Structure of Autonomous Public Healthcare Centres. Argumenta Oeconomica, 1 (28), 181-214.

Bazzoli, G., Chen, H-F., Zhao, M., \& Lindrooth, R.C. (2008). Hospital Financial Condition and Quality of Patient Care. Health
Economics, 17 (8), 977-995.

Bem, A., Prędkiewicz, K., Prędkiewicz, P., \& Ucieklak-Jeż P. (2014). Determinants of Hospital's Financial Liquidity. Procedia Economics and Finance, 12, 27-36.

Bem, A., Prędkiewicz, P., Ucieklak-Jeż, P., \& Siedlecki, R., (2015). Impact of Hospital's profitability on structure of its liabilities, Business Ethics and CSR. Strategica, 657665.

Bem, A., Predkiewicz, P., Ucieklak-Jeż, P., \& Siedlecki R. (2015a). Profitability versus debt in hospital industry, European Financial Systems. Proceeding of the 12th International Scientific Conference, 20-27.

Bem, A., Siedlecki, R., Prędkiewicz, P., Gazzola, P., Ryszawska, B., \& Ucieklak-Jeż P. (2019). Hospitals' Financial Health in Rural and Urban Areas in Poland: Does it 
Ensure Sustainability? Sustainability, 11, 1932.

Bem, A., Siedlecki, R., Prędkiewicz, P., \& Ucieklak-Jeż, P. (2018). Determinants of hospital's financial distress. Central European Conference in Finance and Economics (CEFE2018), Herlany, Slovak Republic, 0406.09.2018, 27-34.

Breyer, F., Costa-Font, J., \& Felder, S. (2010). Ageing, health and health care. Oxford Review of Economic Policy, 26(4), 674-690.

Canadian Insitute for Health Information (2011). Health Care Cost Drivers: The Facts. Ottawa, Ont.: CIHI.

Collum, T.H. (2013). Hospital Financial Performance: A Look at Governance and Hit Strategies. A Dissertation, University of Alabama at Birmingham, Birmingham, Alabama, 2013.

Coyne, J.S., Ricgards, M., Short, R., Shultz, K., \& Singh S. (2009). Hospital Cost and Efficiency: Do Hospital Size and Ownership Type Really Matter? Journal of Healthcare Management, 54 (3), 163-175.

Creixans-Tenas, J., \& Arimany-Serrat N. (2018). Influential variables on the profitability of hospital companies. Intangible Capital, 14 (1), 171-185.

Darvas, Z., Moes, N., Myachenkova, Y., \& Pichler, D. (2018). The macroeconomic implications of healthcare. Policy Contribution, 11, 1-22.

Doeksen, G.A, Johnson, T.G., BiardHolmes, D., \& Schott, V. (1998). A Healthy Sector is Crucial for Community Economic Development. The Journal of Rural Health, 14 (1), 66-72.

Etizoni, A. (1964). Modern organizations. New Jersey, USA: Prentice-Hall.

Final report: study on the representativeness of business organisations for SMEs in the European Union. https://ec.europa.eu/DocsRoom/documents/2 480/attachments/1/translations/en/renditions/ pdf

Gapenski, L., \& Pink, G. (2007). Understanding healthcare financial management. Chicago, USA: Health Administration Press.

GlobalInsight. (2002). Hospital Compensation Costs:

An Analysis Of Escalation In ECI Wage And Benefit Cost Indices Relative To PPS Proxies. Global Insight Inc., https://www.cms.gov/Research-StatisticsData-and-Systems/Statistics-Trends-andReports/MedicareProgramRatesStats/Downlo ads/wagestudyfinal.pdf

Health and Health Care in 2016. (2017). Statistics Poland, https://stat.gov.pl. (in Polish)

Health and Health Care in 2017. (2019). Statistics Poland, https://stat.gov.pl. (in Polish)

Health at a Glance 2015. (2015). OECD Indicators. Paris, Fr: OECD Publishing.

Health at a Glance 2017 (2017). OECD Indicators. Paris, Fr: OECD Publishing.

Hollingsworth, B. (2008). The measurement of efficiency and productivity of health care delivery. Health Economics, 10, 1107-1128.

Horgan, D., van Kranen, H.J., \& Morré, S.A. (2018). Optimising SME Potential in Modern Healthcare Systems: Challenges, Opportunities and Policy Recommendations. Public Health Genomics, 21, 1-17.

Holmes, G.M., Kaufman, B.G. \& Pink G.H. (2017). Predicting Financial Distress and Closure in Rural Hospitals. Journal of Rural Health, 33 (3), 239-249.

Horwitz, J.R. (2005). Making Profits and Providing Care: Comparing Non-profit, ForProfit, And Government Hospitals. Health Affairs, 3, 790-801.

Janati, A., Valizadeh, S., \& AsghariJafarabadi, M. (2014). Development of 
Financial Indicators of Hospital Performance. European Group of Organisation Studies Journal of Clinical Research \& Governance, EGOS 2014, Rotterdam, Holland. 3, 92-98.

Kalman, N.S., Hammil, B.G., Schulman, K.A., \& Shah, B.R. (2015). Hospital Overhead Costs: The Neglected Driver of Health Care Spending? Journal of Health Care Finance, Spring, 41 (4), 1-15.

Kazahaya, G. (2005). Harnessing technology to redesign labor cost management reports: labor costs typically represent over 50 percent of a hospital's total operating expenses. Can the data management process be harnessed to create meaningful labor cost management tools? Healthcare Financial Management, 59 (4), 94-100.

Kaur, D., \& Srivastava, S. (2017). Corporate Debt Restructuring and Firm Performance: A Study of Indian Firms. Serbian Journal of Management, 12 (2), 271281.

Kirshbaum, M.N., Dent, J., Stephenson, J., Topping, A.E., Allinson, V., McCoy, M., \& Brayford, S. (2017). Open access follow-up care for early breast cancer: a randomised controlled quality of life analysis. European Journal of Cancer Care (Engl), 26 (4): e12577.

Koval, O., Nabareseh, S., Stankalla, R., \& Chromjakova, F. (2019). Continuous Improvement and Organizational Pracitices in Service Firms: Exploring Impact on Cost Reduction. Serbian Journal of Management, 14 (1), 177-191.

Locke, R.R., \& Spender, J.C. (2011). Confronting managerialism: how business elite and their schools threw our lives out of balance. London, UK: Zed Books.

Meyer, V.Jr., Pascuci, L., \& Mamedio, D. (2014). Managerialism in non-profit Hospitals: Experiencing strategic practices in complex and hybrid organizations. Proceedings of 30th Annual Colloquium of
Mills, J., Neely A., Platts, K., \& Gregory, M. (1998). Manufacturing strategy: a pictoral representation. International Journal of Operations \& Production Management, 18 (11), 1067 -1085.

Milosevic, I., Mihajlovic I., Stojanovic, A. (2019). Dominanct factors of SMEs failure multigropu confirmatory factor analysis. Serbian Journal of Management, 14 (20), 345-360.

Mohanty, B., \& Mehrotra, S. (2018). Relationship between Liquidity and Profitability: An Exploratory Study of SMEs in India. Emerging Economy Studies, 4 (2), 169-181

Muneer, S., Ahmad, R.A., Ali, A. (2017). Impact on Financial Management Practices on SMEs Profitability with Moderating Role of Agency Costs. Information Management and Business Review, 9 (1), 23-30.

Nyabwanga, R.N., Ojera, P., Otieno, S., Nyakundi, F.N. (2013). An Empirical Analysis of the Liquidity, Solvency and Financial Health of Small and Medium Sized Enterprises in Kisii Municipality. European Journal of Business and Management, 5 (8), $1-15$.

Odit, M., \& Gobardhun, Y.D. (2011). The Determinants Of Financial Leverage Of SME's In Mauritius. International Business \& Economics Research Journal (IBER), 10 (3), 113-126.

Pascuci, L.M., Junior, V.M., \& Crubellate J.M. (2017). Strategic Management in Hospitals: Tensions between the Managerial and Institutional Lens. Brazilian Administration Review, 14 (2), e160092

Pink, G.H., Holmes, M., D’Alpe, C., Strunk, L.A., McGee, P., \& Slifkin, R.T. (2006). Financial Indicators for Critical Access Hospitals. The Journal of Rural Health, 22 (3), 229-236. 
Report on Support to SMEs in Developing Countries Through Financial Intermediaries, (2011).

Dallberg, https://www.eib.org/attachments/dalberg_sm e-briefing-paper.pdf

Rudawska, I. (2012). Epidemiologic and demographic trends as a challenge for European health care systems. Problemy Zarządzania, 11 (41), 34-52.(in Polish)

Ryć, K., \& Skrzypczak, Z. (2012). Health care financing in turbulent global economy. Problemy Zarządzania, 11, 2 (41), 9-23. (in Polish)

Schumann, T.M. (2008). Hospital financial performance trends to watch. Healthcare Financial Management, 62 (7), 59-66.

Smythe, M.S, Koerber, J.M., Fitzgerald, M., \& Mattson J.C. (2009). The financial impact of heparin-inducted thrombocytopenia. Chest, 134 (3), 568-573.

Statistical Yearbook of the Republic of Poland 2017 (2018). Warszawa, Poland: GUS (in Polish)

Street, A., Scheller-Kreinsen, D., Geissler, A., \& Busse R. (2010). Determinants of hospital costs and performance variation: Methods, models and variables for the EuroDRG project. Working Papers in Health Policy and Management, vol. 3, Berlin, DE: Technische Universitat Berlin.

Szewieczek, A. (2018). The analysis of health care market development in Poland its directions and threats, FIKUSZ Symposium for Young Researchers. Proceedings, Obuda University, Budapest, Hungary, 409-424.

Thanasas, G. L. (2013). Factors' Affecting the Hospital's Cost Structure: the Case of a Greek University Hospital. Universal Journal of Accounting and Finance, 1 (2), 78-83.

The 2018 Ageing Report: Economic and Budgetary Projections for the EU Member States (2016-2070), (2018), European Commision,
Turcotte-Tremblay, A.-M., Spagnolo, J., De Allegri, M., \& Ridde, V. (2016). Does performance-based financing increase value for money in low- and middle- income countries? A systematic review, Health Economics Review, 6:30 (https://doi.org/10.1186/s13561-016-0103-9)

www1, (2018). The "Survey on the access to finance of enterprises" (SAFE) was published today. https://ec.europa.eu/growth/content/surveyaccess-finance-enterprises-safe-waspublished-today_en

www2, (2018). Why are so many of our health services provided by charities? https://www.irishtimes.com/life-andstyle/health-family/why-are-so-many-of-ourhealth-services-provided-by-charities1.3300058

www3, (2019). Central Statistical Office, Local data Bank, https://bdl.stat.gov.pl/BDL/start

Velez-Gonzales, H., Pradhan, R., \& Weech-Maldonado, R. (2011). The role of non-financial performance measures in predicting hospital financial performance: the case of for- profit system hospitals. Journal of Health Care Finance, 38 (2), 12-23.

Young, D.W., \& Ballarin., E. (2006). Strategic Decision-Making in Healthcare Organizations: It Is Time to Get Serious. International Journal of Health Planning and Management 21, 173-91.

Younis, M.Z. (2012). A comparison study of urban and small rural hospitals financial and economic performance. Online Journal Rural Nursing Healthcare, 4, 38-48.

Zeller, T.L., Stanko, B.B., \& Cleverey, W.O. (1996). A revised classification pattern of hospital financial ratios. Journal of Accounting and Public Policy, 2, 161-181. 